University of Louisville

ThinkIR: The University of Louisville's Institutional Repository

Electronic Theses and Dissertations

$12-2013$

\title{
Apical left ventricular cannula sutureless implantation development.
}

Adam D. Scarsella

University of Louisville

Follow this and additional works at: https://ir.library.louisville.edu/etd

\section{Recommended Citation}

Scarsella, Adam D., "Apical left ventricular cannula sutureless implantation development." (2013).

Electronic Theses and Dissertations. Paper 1268.

https://doi.org/10.18297/etd/1268

This Master's Thesis is brought to you for free and open access by ThinkIR: The University of Louisville's Institutional Repository. It has been accepted for inclusion in Electronic Theses and Dissertations by an authorized administrator of ThinkIR: The University of Louisville's Institutional Repository. This title appears here courtesy of the author, who has retained all other copyrights. For more information, please contact thinkir@louisville.edu. 
Apical Left Ventricular Cannula Sutureless Implantation Development

By

Adam D. Scarsella

Bachelor of Science Bioengineering, University of Louisville, May 11, 2012

\author{
A Thesis \\ Submitted to the Faculty of the \\ University of Louisville \\ J.B. Speed School of Engineering \\ as Partial Fulfillment of the Requirements \\ for the Professional Degree
}

MASTER OF ENGINEERING

Department of Bioengineering

December 2013 

Apical Left Ventricular Cannula Sutureless Implantation Development

Submitted by:

Adam D. Scarsella

A Thesis Approved On

(DATE)

by the Following Reading and Examination Committee:

Steven C. Koenig Ph.D., Thesis Director

Kevin G. Soucy Ph.D.

Guruprasad Giridharan Ph.D.

Stuart J. Williams Ph.D. 


\section{ACKNOWLEDGEMENTS}

I would like to thank all those that have helped me reach this point in my academic career. I would like to specifically thank Dr. Paul Linsky and Kevin Soucy for their assistance in completing this thesis; their input was invaluable and assisted immensely. I'd also like to thank my parents for their constant support over 23 years, you have always been there for me and I am forever grateful for all you have sacrificed for me. I'd especially like to thank my mom for the constant reminders to get my thesis finished. Lastly, I would like to thank my girlfriend of far too long for bringing me back to earth whenever times got tough. 


\begin{abstract}
Introduction: Cannulation of the left ventricle (LV) apex is a common surgical procedure for aortic valve bypass and ventricular assist device (VAD) implantation. LV cannulation requires coring of the LV apex and attaching a sewing ring via suture. Although effective, suturing is time-consuming and apical coring can lead to bleeding complications or inflow occlusion. The scope of this project was to design a suturelessanchoring device for an apical left ventricular (ALV) cannula system.
\end{abstract}

Instrumentation, equipment, and procedures: The sutureless-anchoring device was designed as a conical spring. Five prototypes were fabricated with varying wire diameter $(0.045 "-0.055 ")$, maximum cone diameter $(0.85 "-0.975 ")$, and spring height $(0.75 "-$ 1.25”). The conical springs were attached to PVC cylinders to mimic ALV cannulae. The prototypes were tested through 1) leak test with pressurized porcine hearts, 2) tensile pull test using porcine hearts and an INSTRON, and 3) quantitative assessment of device implantation by cardiothoracic surgeons.

Results and Discussion: Leak testing determined that the prototypes created a leak-proof tissue-cannula interface. The prototype with the largest cone and wire diameter combination was able to achieve a tensile failure force similar to that of a clinically-used 
VAD sewing ring. Other prototypes yielded failure forces below the VAD sewing rings. The quantitative assessment reported that the prototype easily penetrates the tissue and is quicker to implant than sewing rings.

Conclusions: This preliminary study demonstrated promise for a sutureless-anchoring device as part of an ALV cannula system. A sutureless implantation method may lead to safer and faster LV cannulation surgeries, thus improving patient outcomes and reducing surgical cost.

Recommendations: It is recommended to test springs with larger wire diameter and large end outer diameter combinations than those tested in this study. It is also recommended to create and test multiple prototypes of each variation of spring dimensions. 
TABLE OF CONTENTS

APPROVAL PAGE....................................................................................... ii

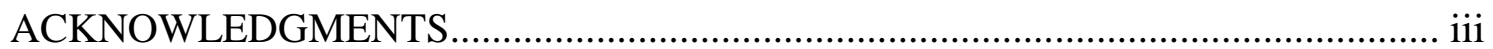

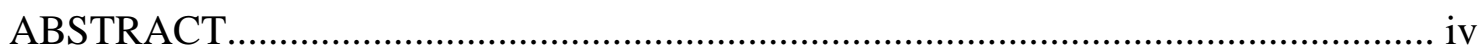

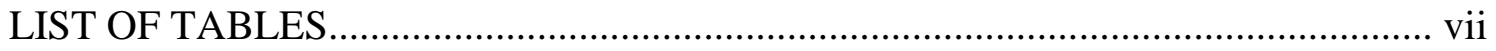

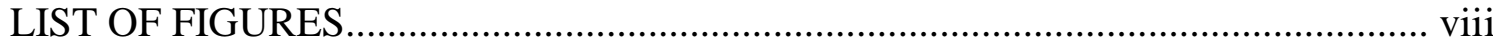

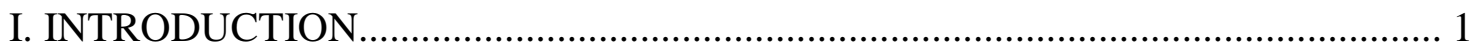

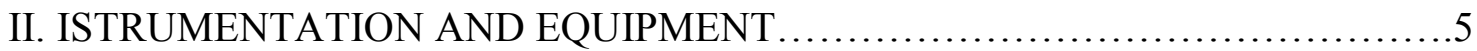

A. FABRICATION OF DEVICE....................................... 5

B. PREPARATION FOR LEAK TESTING..............................6

C. PREPARATION FOR TENSILE TESTING..............................7

D. PREPARATION FOR QUANTITATIVE FEASIBILITY OF IMPLANTATION SUVEY ............................................9

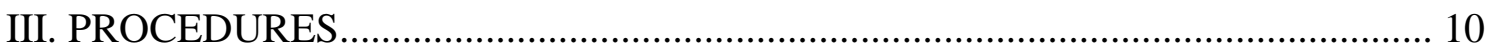

A. PROCEDURE FOR FABRICATING PROTOTYPES............................... 10

B. PROCEDURE FOR PERFORMING LEAK TESTING .................... 12

C. PROCEDURE FOR TENSILE TESTING .............................. 15

D. PROCEDURE FOR QUANTITATIVE FEASIBILITY OF IMPLANTATION

SURVEY .................................................. 18

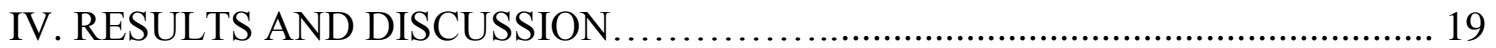

A. RESULTS AND DISCUSSION OF LEAK TEST ..................................... 19

B. RESULTS AND DISCUSSION OF TENSILE TEST ................................ 22

C. RESULTS AND DISCUSSION OF QUANTITATIVE FEASIBILITY OF

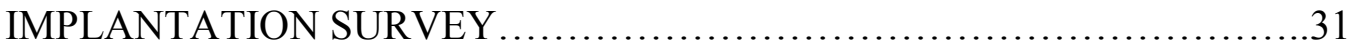

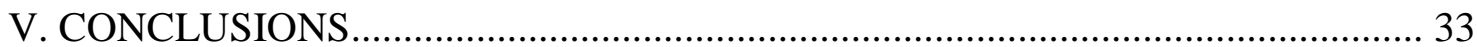

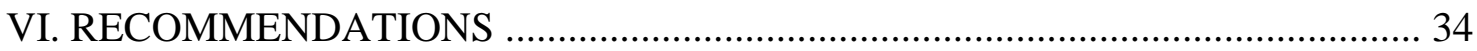

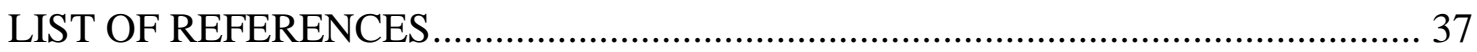

APPENDIX I. QUATITATIVE FEASIBILITY OF IMPLANTATION SURVEY AND

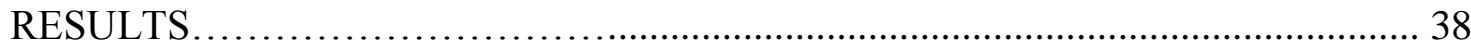




\section{LIST OF TABLES}

TABLE I - PRELIMINARY PULL TEST RESULTS USING SPRING SCALE........6 TABLE II - LIST OF SPRINGS AND DIMENSIONS USED FOR THIS STUDY .....12

TABLE III - RESULTS FROM LEAK TESTING................................ 19

TABLE IV - AVERAGE PRESSURE FROM LEAK TESTING BY WIRE

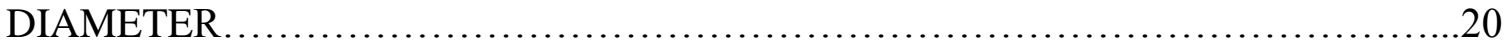

TABLE V - RESULTS FROM TENSILE TESTING .............................24

TABLE VI - MAXIMUM AND AVERAGE FORCES FOR SEWING RING TENSILE

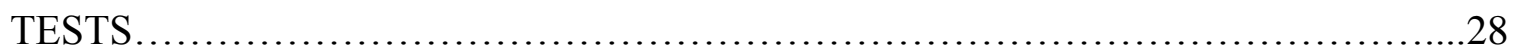

TABLE VII - RESULTS FROM ALL TENSILE TESTS......................... 30

TABLE VIII - RESULTS OF QUANTITATIVE SURVEY OF DEVICE..............32

TABLE IX - RECOMMENDED SPRINGS FOR FUTURE TESTING................36 


\section{LIST OF FIGURES}

FIGURE 1 - Pictures of Transapical and Transfemoral Valve Implantation Techniques...3

FIGURE 2 - Screw in pacemaker lead......................................

FIGURE 3 - 1) Large end outer diameter, 2) Length, 3) Wire diameter.................5

FIGURE 4 - Electrical box on INSTRON base (left) and bolts securing box (right)......7

FIGURE $5-1$ " S hook secured in upper grips of INSTRON $\ldots \ldots \ldots \ldots \ldots \ldots \ldots \ldots \ldots \ldots$

FIGURE 6 - Left: Two Heartmate II sewing rings. RIGHT: Two HVAD sewing rings...9

FIGURE 7 - Hole cut into apex of heart for cannula prototype implantation............9

FIGURE 8 - Example of a cutting suture needle tip............................ 10

FIGURE 9 - Sharpened spring and noticeable upwards angle......................11

FIGURE 10 - Foley Catheter port set up 1) 10mL syringe for inflating balloon on foley

2) Bulb suction syringe for applying pressure 3) Monometer for measuring pressure in

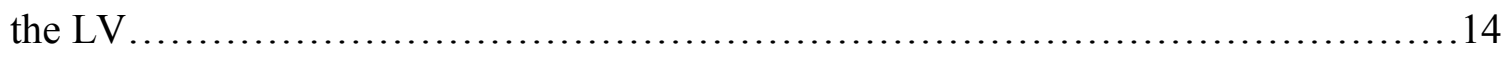




\section{LIST OF FIGURES (CONTINUED)}

FIGURE 11 - Leak testing set up: 1) Cannula prototype 2) Foley Catheter occluding mitral valve 3)hemostat clamping off aorta 4) pressure being applied to ball suction

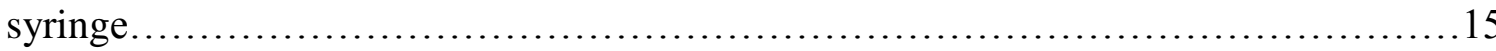

FIGURE 12 - Tensile pull testing set up......................................16

FIGURE 13 - Left: 3/4” S hooks hooked under the Heartmate II sewing ring. Right: 2

3/4"S hooks hooked under HVAD sewing ring and into the 1 " $\mathrm{S}$ hook in INSTRON

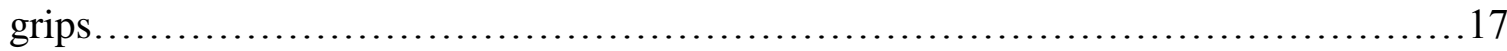

FIGURE 14 - Graphs of the results from tensile pull testing for cannula prototypes......23

FIGURE 15 - Best subsets analysis of Average Force (N) vs. Large outer diameter, Wire

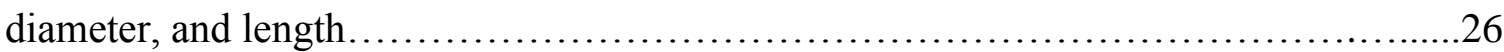

FIGURE 16 - Regression analysis results of Average force vs. large outer diameter and

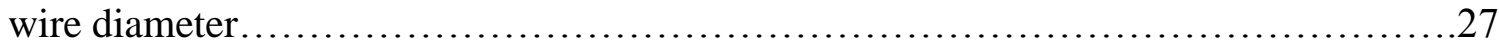

FIGURE 17 - Graphs of Tensile pull test data for sewing rings....................27 


\section{INTRODUCTION}

Cannulation of the left ventricle (LV) apex is a common surgical procedure for aortic valve bypass and ventricular assist device (VAD) implantation. LV cannulation requires coring of the LV apex and attaching a sewing ring via suture. Although effective, suturing is time-consuming and apical coring can lead to bleeding complications or inflow occlusion.

The scope of this project was to design a sutureless-anchoring device for an apical left ventricular (ALV) cannula system. The selected design for the sutureless-anchoring device is a conical screw attached to the cannula, which will be implanted into the heart using the Seldinger technique. A small incision will be made in the apex of the heart and then using dilating catheters, the incision will be dilated to the appropriate size and the cannula will be fed over the final catheter into the apex. The cannula will then be secured in place, by turning the cannula clockwise until the screw is fully embedded in the heart. It will then be connected to either a Dacron graft for aortic valve bypass (AVB) or a VAD for device implantation. This will remove the need for sewing rings and coring of the heart, theoretically, reducing time of procedure and blood loss.

There are current procedures in place for aortic stenosis treatment and VAD imlantation that have reduced the amount of blood loss and need for coring of the apex. One such method for treating patients with aortic stenosis is aortic valve replamcent via transcatheter valve implantation (TVI). In TVI a balloon catheter is fed through the apex of the heart or the femoral artery into the aortic valve opening. Once the catheter has 
been fed into the aortic valve opening the balloon is inflated and a stent with a porcine valve is secured in the place of the original aortic valve (FIGURE 1). It has been shown that, when the TVI expands the native valve, calcium deposits breakoff increasing the risk for cerebral embolisms and stroke [1,2]. Traditionally, patients with severe aortic stenosis that were considered high risk were denied treatment as aortic valve replacement surgery is invasive and could lead to perioperative mortality and morbidity with this group of patients. However, TVI and AVB are both suitable procedures for patients that have severe aortic stenosis and are high risk. Unique LVAD designs have similarly removed the need for apical coring, such as the Impella LD, a temporary LVAD. Implantation of the Impella LD is through an incision in the femoral artery; the device is then fed into the left ventricle through the aortic valve and remains there. The Impella system is only intended to provide temporary treatment and has limited flow support. The maximum outflow of the Impella system is $5.3 \mathrm{~L} / \mathrm{min}$, half the inflow of other LVAD systems [3,4]. Both of these methods eliminate the need for apical cannulation and coring however they still have limitations that an ALV system overcomes. The proposed ALV cannula system is a permanent solution implanted into the apex of the heart so it does not come into contact with the aortic valve, reducing the potential for embolisms originating from a manipulated valve. 

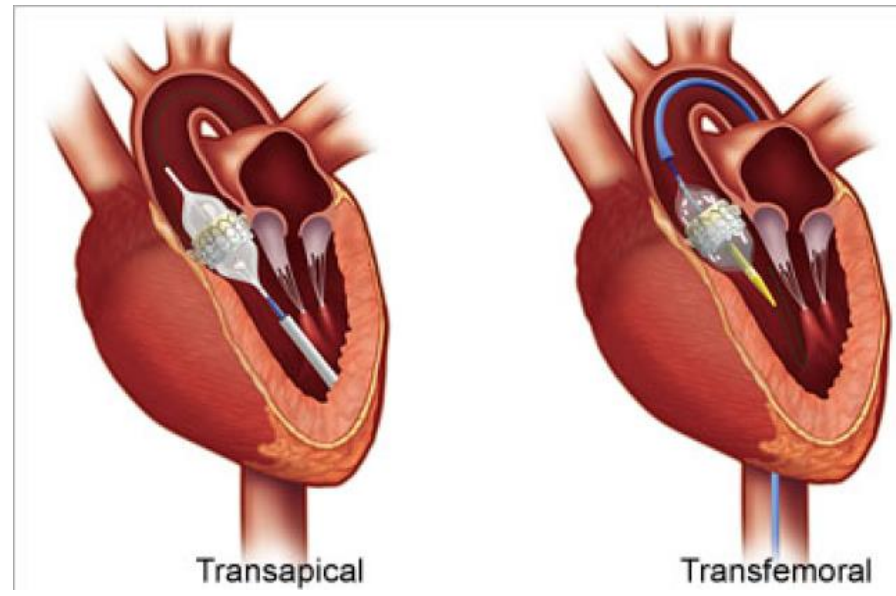

FIGURE 1- Pictures of Transapical and Transfemoral Valve Implantation Techniques

After an extensive literature review, it was found that there are no suturelessanchoring devices on the market currently. Similar ideas of securing devices in the heart using a screw can be found with pacemaker leads. One type of pacemaker lead utilizes a helical screw to position the lead in the heart (FIGURE 2). The pacemaker screw is used for securement of the lead to the heart and emission of electrical signals for pacing. The screws in this study are conical and intended purpose is solely for securement of the cannula system in the heart.

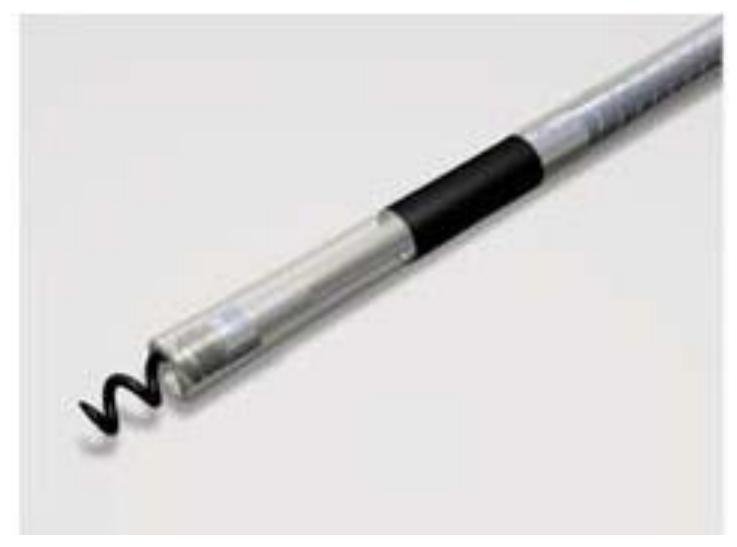

FIGURE 2- Screw in pacemaker lead 
The conical screw design for the sutureless anchoring device is constrained by two critical features: 1) LV wall thickness (anatomical feature), and 2) cannula inflow tip outer diameter (device feature). Through recommendations from experienced clinical professionals, as well as, dimensions found in papers it was determined the wall thickness at the apex of the heart ranged from 19-30mm (0.75"-1.18") in patients with severe left ventricular hypotrophy $[5,6]$. These values were used to determine the lengths of screws to use for this study. The cannula inflow tip outer diameter from previous studies determined that the optimum outer diameter for the cannula was $14 \mathrm{~mm}$ $\left(0.55^{\prime}\right)$. This value was used to determine the large end outer diameter for the springs in this study. The outer diameter was chosen so that it would allow clearance around the cannula, but not too large that would inhibit the screw from penetrating the heart.

The sutureless-anchoring device for an ALV cannula system in this study is meant to eliminate the need for sewing rings and coring of the heart. The coring of the heart will be eliminated through the use of the previously explained Seldinger technique and the sewing rings will be eliminated through the screw itself. To determine feasibility of the proposed sutureless-anchoring device as an acceptable alternative to sewing rings three tests were performed. The first test was a leak test that utilized pressurized hearts with the cannula system implanted into the apex to determine if there was any leakage at the cannula-tissue interface. The second test was a tensile pull test that determined the failure force of the cannula prototypes compared to LVAD-specific sewing rings. The third test was a quantitative evaluation of the prototypes by cardiothoracic surgeons. They administered the prototypes to a heart and provided feedback about the feasibility of implantation and ease of use as compared to a sewing ring. 


\section{INSTRUMENTATION AND EQUIPMENT}

\section{A. Fabrication of Device}

The sutureless anchoring device prototypes were fabricated using stainless steel conical springs (McMaster-Carr). Springs were selected so that there was variation in length, large end outer diameter, and wire diameter (FIGURE 3). .

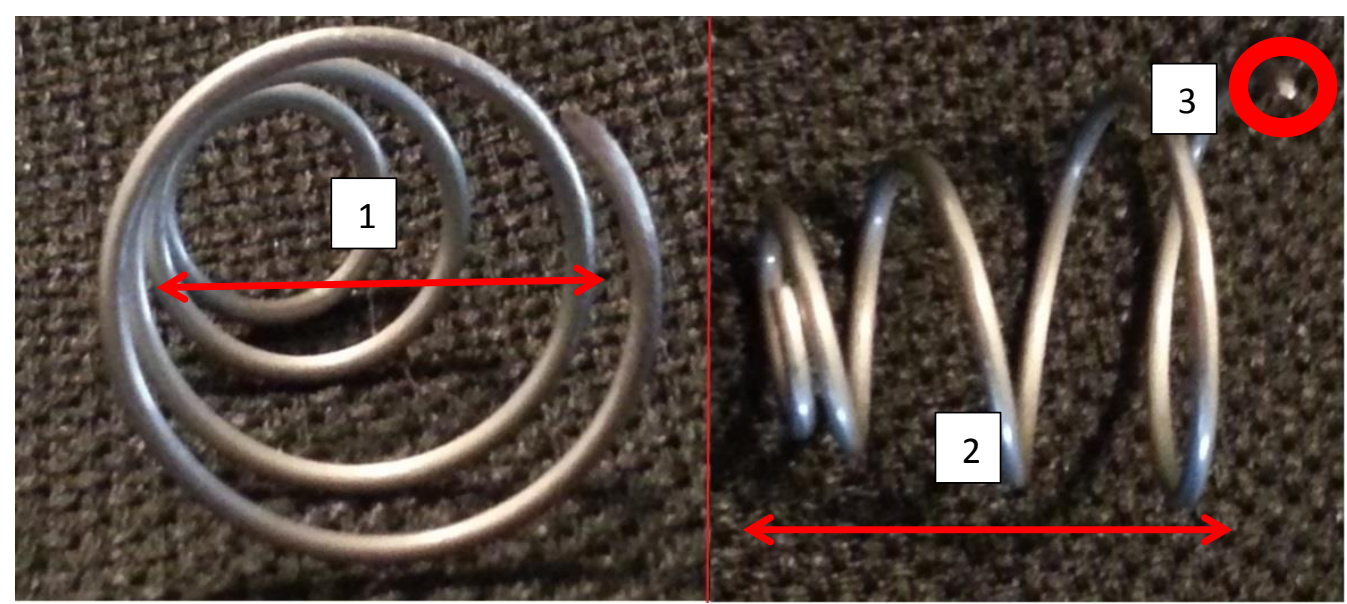

FIGURE 3: 1) Large end outer diameter, 2) Length, 3) Wire diameter

Spring dimensions of length, large-end diameter, and small-end diameter satisfied the anatomical (LV wall thickness) and device constraints (cannula outer diameter), as described above (Table II). One side effect of aortic stenosis is left ventricular hypertrophy [7]. Because of this, a longer spring can be used, however, in this study no springs were used that were longer than $1 \frac{1}{4}$ ”. Preliminary tests using a Rapala $50 \mathrm{lb}$ capacity spring scale showed that as wire diameter increased so too did the amount of force required to remove the spring from tissue (Table I). 


\section{TABLE I}

\section{PRELIMINARY PULL TEST RESULTS USING SPRING SCALE}

\begin{tabular}{|c|c|c|l|}
\hline $\begin{array}{c}\text { Spring } \\
\text { Number }\end{array}$ & $\begin{array}{c}\text { Wire } \\
\text { Diameter }\end{array}$ & $\begin{array}{c}\text { Failure Force } \\
\text { (Ibs.) }\end{array}$ & \multicolumn{1}{|c|}{ Observations } \\
\hline 1 & $.038^{\prime \prime}$ & 8 & $\begin{array}{l}\text { Irreversible } \\
\text { Deformation occurred }\end{array}$ \\
\hline 2 & $.040^{\prime \prime}$ & N/A* & $\begin{array}{l}\text { Up to 10lbs of force } \\
\text { applied, did not pull } \\
\text { out }\end{array}$ \\
\hline 3 & $.042^{\prime \prime}$ & N/A* & $\begin{array}{l}\text { Up to 10lbs of force } \\
\text { applied, did not pull } \\
\text { out }\end{array}$ \\
\hline 4 & $.049^{\prime \prime}$ & 13 & $\begin{array}{l}\text { Began to pull out of } \\
\text { tissue }\end{array}$ \\
\hline 5 & $.055^{\prime \prime}$ & 17 & $\begin{array}{l}\text { Began to rip tissue at } \\
\text { insertion point }\end{array}$ \\
\hline
\end{tabular}

*Did not measure failure force due to lack of sound tissue remaining

The large end outer diameters were determined to be larger than the outer diameter of the material being used to mimic the cannula. Depending on the thickness of the spring, diagonal cutters or a Dremel with metal cutting circular saw attachment and a hand file were used to prepare the spring. Half inch outer diameter hollow PVC tubing was used to mimic the $14 \mathrm{~mm}$ diameter cannula.

\section{B. Preparation for Leak Testing}

The following items were used for leak testing: scalpel, Foley Catheter with irrigation port, forceps, several hemostats, Curved Mayo surgical scissors, tray, bulb suction syringe, $10 \mathrm{ml}$ syringe, cup of water, hearts, and Smart Manometer M2series pressure manometer. All hearts in this study were porcine hearts that were donated for educational purposes from either Boone's Butcher Shop (Bardstown, KY), or JBS Swift \& Co. (Louisville, KY). 


\section{Preparation for Tensile Testing}

The following items were used for tensile pull testing: two $3 / 4$ " S hooks, one 1" $\mathrm{S}$ hook, a 6"x6"x4" (LxWxD) square electrical conduit box with a 2" diameter circular hole in the lid and accompanying screws, square plastic container fitted to the conduit, hearts, surgical gloves, biohazard bags, sanitation equipment, a Phillips head screwdriver, and a scalpel. This test was performed to determine the failure force required to remove the cannula apparatus from the heart. This study used an INSTRON model 4505 for tensile testing. The equipment was located in the Department of Mechanical Engineering Testing Laboratory at the University of Louisville. An electrical conduit box was used in place of the INSTRON base to accommodate the pig hearts (FIGURE 4).

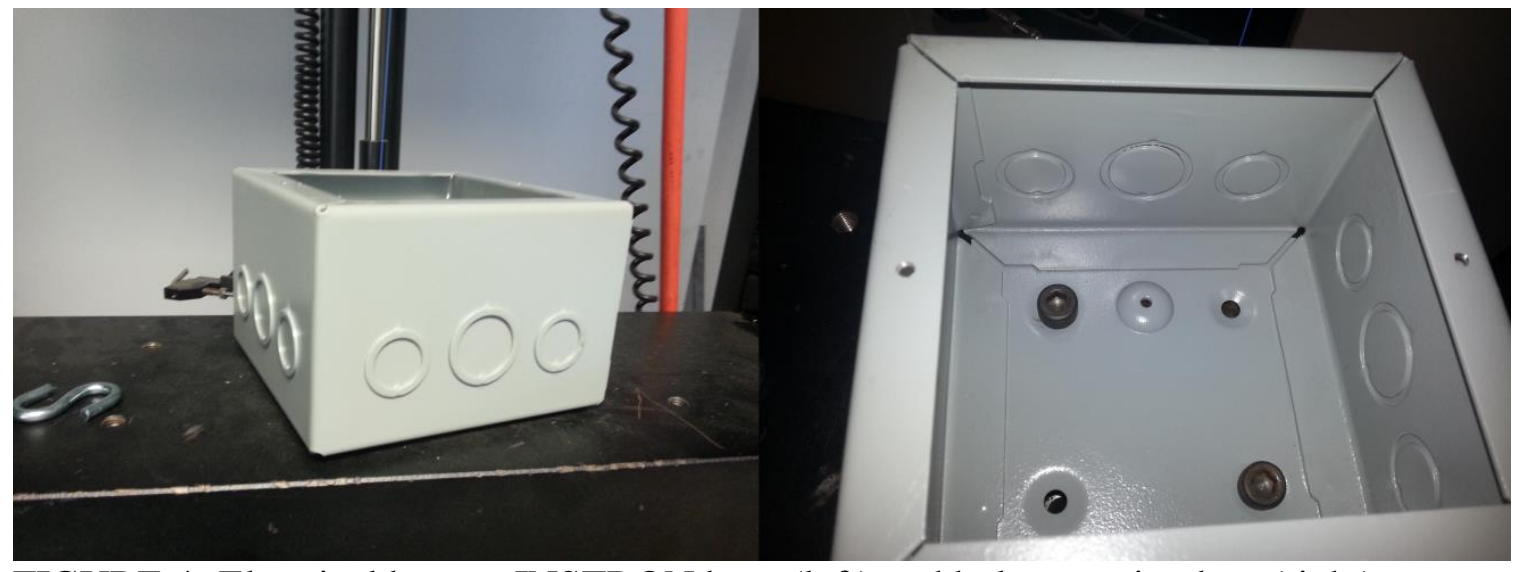

FIGURE 4- Electrical box on INSTRON base (left) and bolts securing box (right)

After the conduit box was secured to the INSTRON base, the 1" S hook was placed in the upper grips (FIGURE 5). 


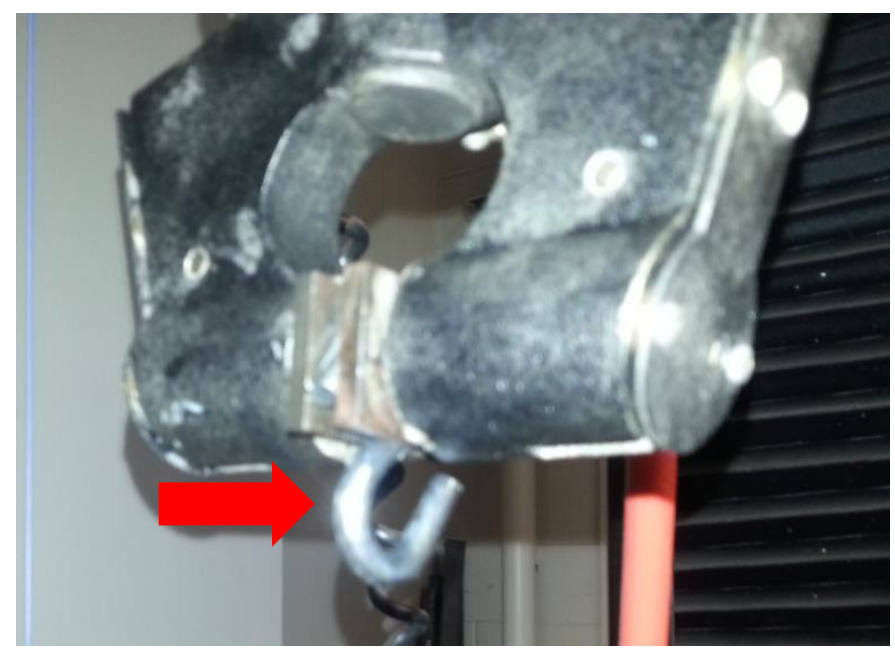

FIGURE 5- 1"S hook secured in upper grips of INSTRON

The INSTRON was programmed to run the samples at a tensile rate of $12 \mathrm{~mm} / \mathrm{minute}$.

This rate was held constant because variations in the rate could lead to differences in the results between trials.

The results of the tensile test on each cannula were compared to a control using four sewing rings, two Heartmate II and two HVAD (FIGURE 6). Each ring was sewn to a separate heart by an experienced cardiothoracic surgeon using 2-0 Microfilament sutures and pledgets. For this study eight pledgets and sutures were used for each sewing ringThe attached sewing rings were connected to the Instron setup using the same method and materials as described for the cannula prototypes. 


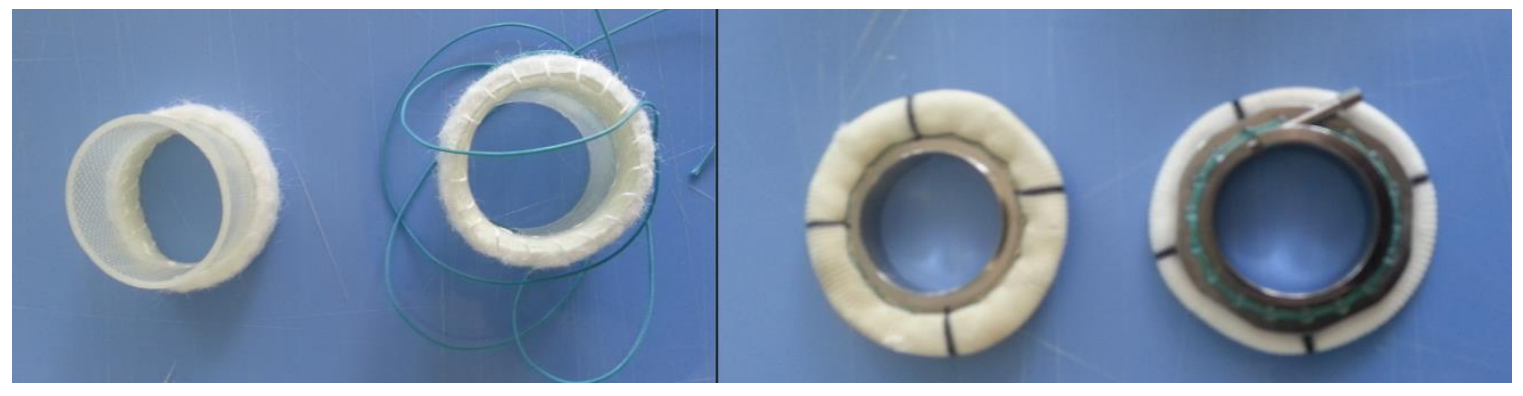

FIGURE 6- Left: Two Heartmate II sewing rings. RIGHT: Two HVAD sewing rings.

D. Preparation for Quantitative Feasibility of Implantation Survey

Prior to the survey of cardiothoracic surgeons the following items were obtained: porcine hearts, scalpel, surgical gloves, and copies of the survey form found in APPENDIX I. Hearts were prepared for the surgeons using a scalpel to cut a hole in the apex of the heart that was no larger than a dime (FIGURE 7).

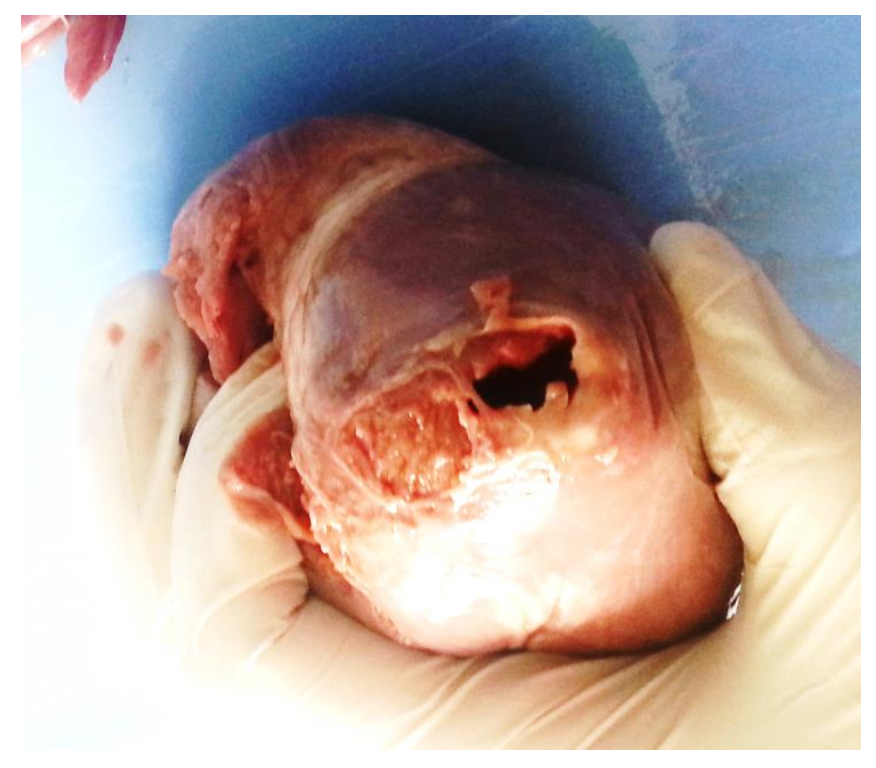

FIGURE 7- Hole cut into apex of heart for cannula prototype implantation. 


\section{PROCEDURES}

\section{A. Procedure for fabricating prototypes}

Fabrication of the cannula prototypes was started by sharpening the tip of the spring on the large outer diameter end. The springs used in this study required a portion of the tip to be removed; this was done on some springs with the diagonal cutters, and others using the Dremel with the metal cutting circular saw attachment. Once the tip was removed, the newly exposed face was sharpened to mimic the tip of a cutting suture needle (FIGURE 8) using a hand file. This was done by sharpening each side so they formed a triangle with the top portion of the spring being flat.

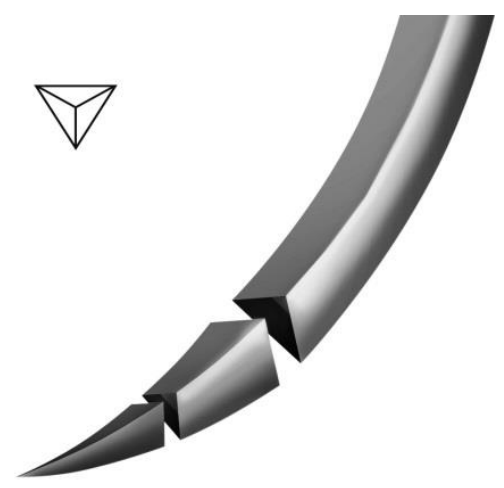

FIGURE 8- Example of a cutting suture needle tip

The spring was also sharpened so there was a slight upwards angle on the tip to facilitate initial penetration of the tissue. A sharpened spring can be seen in FIGURE 9 below. 


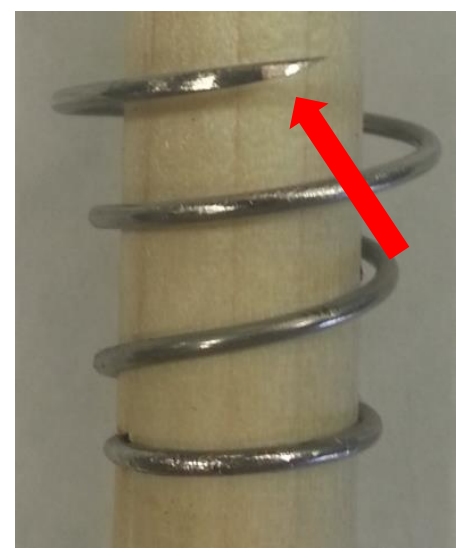

FIGURE 9- Sharpened spring and noticeable upwards angle

Sharpened springs were attached to 6-inch lengths of PVC tube to model the ALV cannula tip. Using the Dremel and 1/20" drillbit, a hole was drilled into the tubing approximately 1.5 " from one end of the tubing. The spring was then trimmed on the small outer diameter end until it was able to slip over the outside portion of the tubing. After it was trimmed, it was positioned on the tubing so that the sharp tip was facing the short end of the tubing and the trimmed small outer diameter end of the spring was positioned in the hole. Using the hand file, the short end of the tubing was rounded off so there were no sharp edges to affect the tissue during insertion. This study utilized five separate springs with varying length, wire diameter, and large end outer diameter (Table II). The number corresponding to each spring in the table will be how the springs are referred to through the rest of the paper. As stated earlier, no spring should exceed $1 \frac{1 / 4 "}{4}$ in length. In addition, no spring was used that was shorter than $3 / 4$ " in length to ensure deep implantation into the cardiac tissue. As stated earlier, in preliminary studies it was found that as wire diameter increased so too did the failure force (Table I). Because of this, no springs were used with a smaller wire diameter than .045 " while no springs were used that had a larger wire diameter than .055 " due to limitations from McMaster-Carr. 
Large end outer diameter was either .975 " or .85 " because those measurements allow clearance around the cannula prototype; however, it was not too large to inhibit the tissue from compressing to the cannula. Larger outer diameters could be used but for simplicity only these two values were used in hopes that they would give a better understanding of how large end outer diameter affects test results.

\section{TABLE II}

\section{LIST OF SPRINGS AND DIMENSIONS USED FOR THIS STUDY}

\begin{tabular}{|r|r|r|r|r|}
\hline \multicolumn{1}{|c|}{$\begin{array}{c}\text { Spring } \\
\text { Number }\end{array}$} & $\begin{array}{c}\text { Length } \\
\text { (in.) }\end{array}$ & $\begin{array}{c}\text { Large Outer Diameter } \\
\text { (in.) }\end{array}$ & $\begin{array}{c}\text { Small Outer Diameter } \\
\text { (in.) }\end{array}$ & $\begin{array}{c}\text { Wire Diameter } \\
\text { (in.) }\end{array}$ \\
\hline 1 & 1 & 0.975 & 0.5 & 0.055 \\
\hline 2 & 1 & 0.85 & 0.281 & 0.055 \\
\hline 3 & 1.25 & 0.975 & 0.5 & 0.049 \\
\hline 4 & 0.75 & 0.85 & 0.438 & 0.049 \\
\hline 5 & 0.75 & 0.85 & 0.5 & 0.045 \\
\hline
\end{tabular}

\section{B. Procedure for Performing Leak Testing}

Leak testing was completed during this study to ensure the spring was able to form a seal at the tissue-cannula interface at high pressures similar to those experienced in patients with aortic stenosis.

The cannula prototypes (Table II) were obtained and the tubing was filled with plumbers epoxy. The epoxy was administered so that it covered any openings in the prototype so there was no leakage due to prototype fabrication during the testing. Each heart had to be tested prior to ALV cannula insertion to ensure it could be pressurized. 
To pressurize the heart, the aorta was clamped off with a large hemostat to block flow from the left ventricle. Once the aorta was clamped, the foley catheter was passed through the mitral valve into the left ventricle. The $10 \mathrm{ml}$ syringe was filled with water and placed onto the luer lock port on the foley. The syringe was used to fill the balloon on the end of the foley, and then removed so the balloon remained inflated. It was determined that the balloon was occluding the mitral valve by pulling back on the foley. The bulb suction syringe was filled with water and placed in the middle port of the foley, pressure was then applied to the bulb. The heart was analyzed as pressure was being applied for any leaks. If there were any leaks the heart was deemed inappropriate for this study because it was unable to be pressurized. However, if the heart was capable of being pressurized then the bulb suction syringe was removed, the balloon was deflated by administering the syringe to the leur lock, and the foley was removed from the LV. The scalpel was then used to administer a small circular incision, no bigger than a dime (FIGURE 6), through the apex and forceps were used to remove the tissue. The first prototype was inserted into the incision up to the tip of the spring; once the spring came in contact with the tissue, it was turned clockwise until the spring was fully embedded in the tissue. By placing the small finger through the mitral valve, we ensured the spring did not penetrate into the left ventricle on all hearts. Once in place, the foley catheter was reinserted through the mitral valve and the balloon was filled using the $10 \mathrm{ml}$ syringe. It was again ensured that the balloon was occluding the mitral valve, and then the monometer was placed on the third port of the foley catheter (FIGURE 10). 


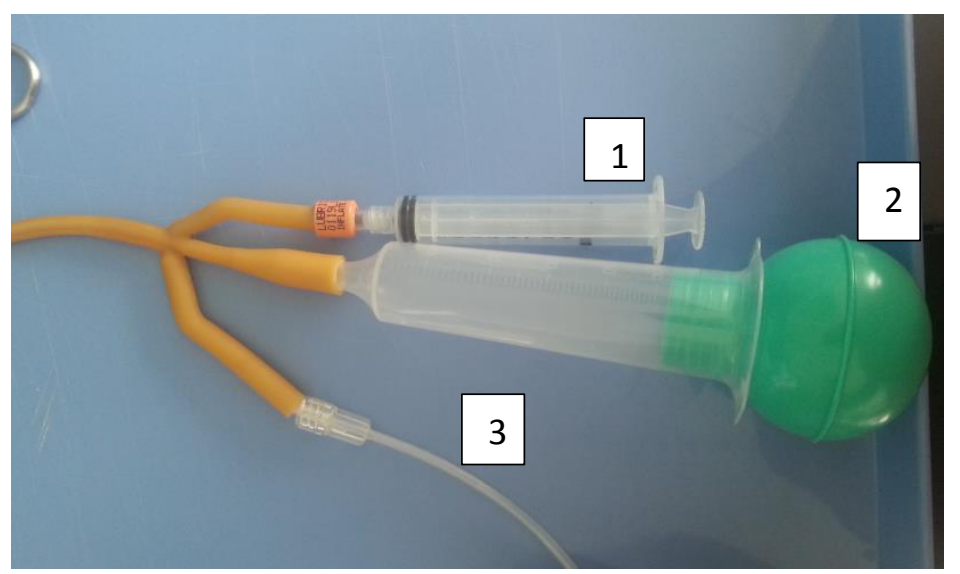

FIGURE 10- Foley Catheter port set up 1) 10mL syringe for inflating balloon on foley 2) Bulb suction syringe for applying pressure 3) Monometer for measuring pressure in the LV

The monometer was zeroed. The bulb suction syringe was filled with water. It was then placed on the foley catheter and pressure was applied to the bulb until a maximum pressure was achieved. The maximum pressure was then recorded. Slight mitral regurgitation consistently occurred due to the lack of a tight seal between the mitral valve and the balloon on the foley catheter, however, the rate of LV pressurization was much greater than the regurgitation so it was assumed that the results were unaffected. As a result of of the regurgitation, it was difficult to increase the pressure in gradual increments; therefore pressure was applied until the maximum pressure was achieved or until a leak occurred from the heart or prototype.

This process was repeated on the same cannula an additional two times. Once testing was completed on one cannula prototype the heart was disposed of and the test was repeated with a new heart and cannula prototype. 


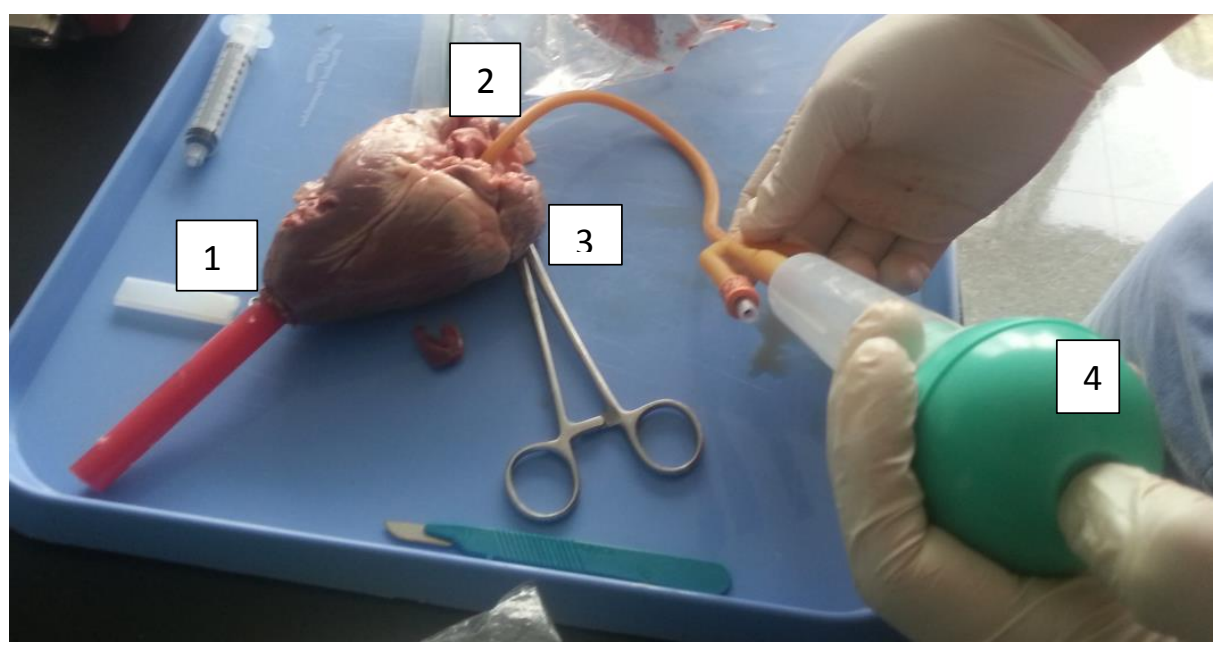

FIGURE 11- Leak testing set up: 1) Cannula prototype 2) Foley Catheter occluding mitral valve 3)hemostat clamping off aorta 4) pressure being applied to ball suction syringe

The roles of each person during this procedure were as follows. One person was used to monitor the monometer for the maximum pressure and to make sure there was no backflow of water into the manometer. This person was responsible for recording the maximum pressure. Another person was in charge of holding the foley catheter in place against the mitral valve because, due to high pressures in the left ventricle and the elasticity of the balloon, the foley catheter could be easily displaced without constant tension. The third person was responsible for applying pressure to the bulb suction syringe and monitoring the heart for any leaks from the cannula or the heart itself.

\section{Procedure for tensile testing}

Using a Dremel with a $1 / 8$ " drill bit, the PVC tubing of all the cannula prototypes had two holes drilled parallel from each other, $1 / 2$ " from the distal end of the tube. The holes were drilled large enough so that the $3 / 4$ " S hooks would fit easily into them. Cannula were ready for tensile testing once the holes were drilled into the tubing. Using 
the scalpel a small circular incision, no larger than a dime (FIGURE 7), was made in the first heart for testing. The prototype was implanted through the hole until the tip of the spring came into contact with the tissue; it was then rotated clockwise until the spring was fully embedded into the tissue. The heart was then placed in the plastic container and the container was positioned in the conduit box secured to the Instron base. The cannula was fed through the 2 " opening in the lid, which was then secured to contain the heart. The two 3/4" S hooks were inserted into the two distal holes on the tubing and hooked onto the 1"S hook (FIGURE 12) by moving the INSTRON base upwards with the controller.

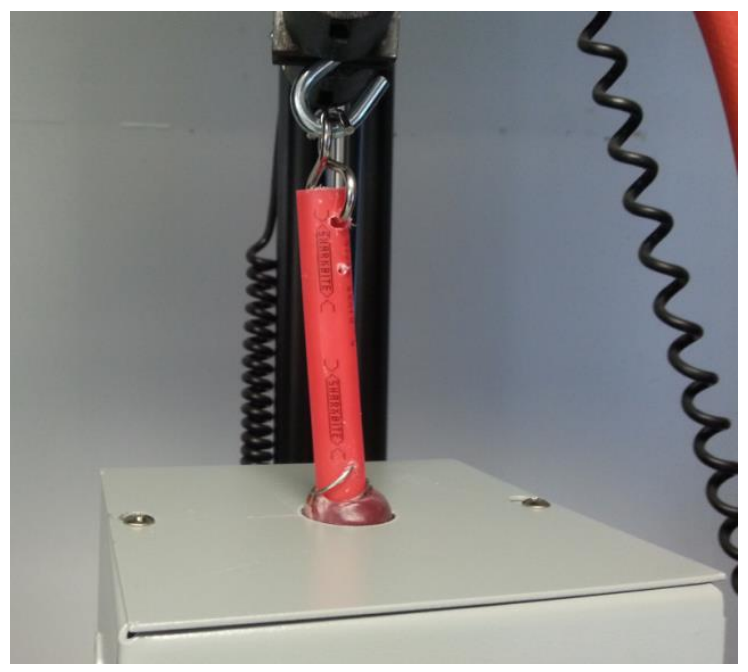

FIGURE 12- Tensile pull testing set up

The INSTRON base was moved down until the portion of the heart with the spring implanted in it began to pass through the hole in the lid (FIGURE 12). This yielded a preload of 5-10N. The cannula was monitored for any irregularities in the tissue as force was applied. The run was complete once the spring was fully removed from the tissue. 
This procedure was performed three times per cannula prototype, with a new heart being used for each run.

To understand the results a control needed to be established. This was completed by comparing results from the prototype tensile testing to tensile tests performed on sewing rings. A heart with sewing ring sutured to it was obtained and the two $3 / 4$ " S hooks were hooked underneath the sewing ring-tissue barrier (FIGURE 13). The INSTRON platform was raised until the two $3 / 4$ " $\mathrm{S}$ could hook into the 1 " $\mathrm{S}$ hook. The platform was the lowered until the sewing ring had passed through the lid of the box. The sewing ring was monitored for any irregularities in the tissue as force was gradually applied. The program was run until the sewing ring was fully removed from the tissue. This procedure was performed for HeartWare HVAD sewing rings $(n=2)$ and Thoratec HeartMate II sewing rings $(n=2)$. The data from each trial was then exported for analysis.

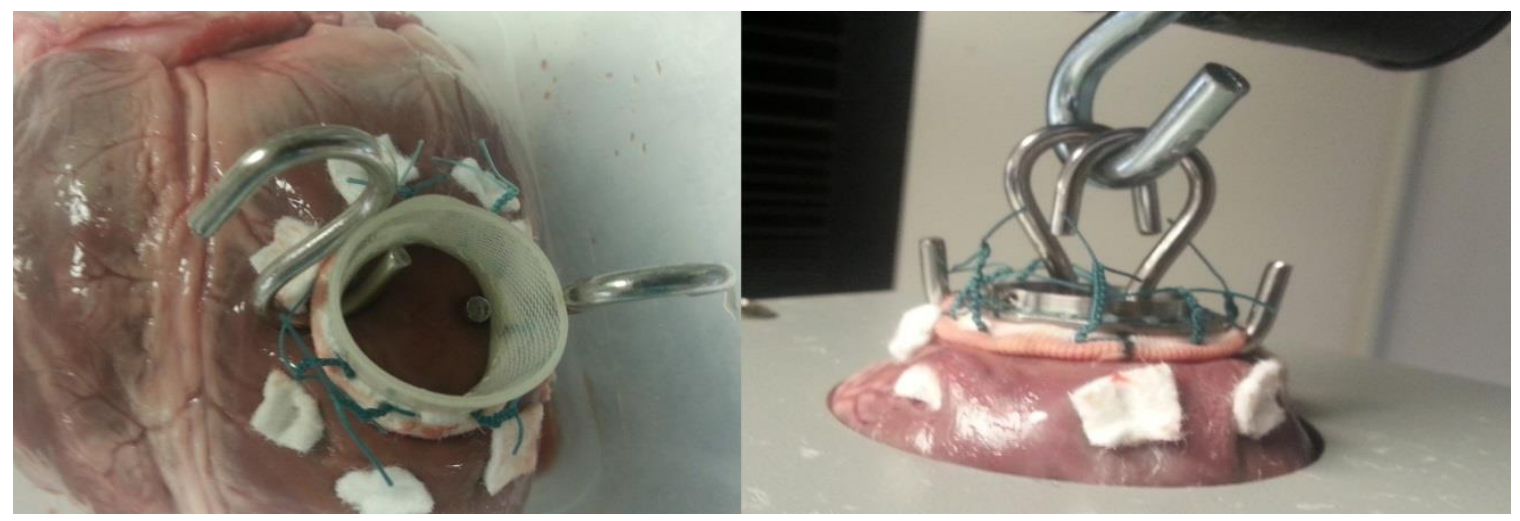

FIGURE 13- Left: 3/4" S hooks hooked under the Heartmate II sewing ring. Right: 2 3/4" S hooks hooked under HVAD sewing ring and into the 1" $\mathrm{S}$ hook in INSTRON grips. 


\section{Procedure for Quantitative Feasibility of Implantation Survey}

Meetings were scheduled with two cardiothoracic surgeons. Prior to their arrival, all hearts, which had circular incisions, were placed on a tray. Cannula prototype 1 was given to the surgeons. The device, its purpose, and brief implantation instructions were then described to surgeons so they understood their purpose in the study and had a basic understanding of how to perform the cannula insertion. They were then instructed to implant the prototype into the heart. After they had implanted the cannula they were administered the survey which can be found in APPENDIX I. Surgeons were able to remain anonymous for this study. After they had taken the survey their results were analyzed. 


\section{RESULTS AND DISCUSSION}

\section{A. Results and Discussion of Leak Test}

The results for leak testing can be found in Table III below. This test was a pass/fail test with passing being considered a test that did not leak at the cannula-tissue interface. A fail is considered any run that produced a leak at the cannula-tissue interface. The goal of this test was to achieve pressure values above $150 \mathrm{mmHg}$, simulating the high pressures experienced in a patient with aortic stenosis [1]. Accordingly, trials that did not reach $150 \mathrm{mmHg}$ due to non-device failures were not considered to be adequate tests of device function.

TABLE III

\section{RESULTS FROM LEAK TESTING}

\begin{tabular}{|c|c|c|c|c|c|c|c|}
\hline \multirow{2}{*}{$\begin{array}{l}\text { Spring } \\
\text { Number }\end{array}$} & \multicolumn{4}{|c|}{ Pressure (mmHg) } & \multirow{2}{*}{$\begin{array}{l}\text { Standard } \\
\text { Deviation }\end{array}$} & \multirow{2}{*}{ Result } & \multirow{2}{*}{ Observations } \\
\hline & $\begin{array}{l}\text { Trial } \\
1\end{array}$ & $\begin{array}{l}\text { Trial } \\
2\end{array}$ & $\begin{array}{l}\text { Trial } \\
3\end{array}$ & Average & & & \\
\hline 1 & 173.0 & 180.9 & 131.4 & $177.0^{*}$ & $5.6^{*}$ & Pass & Septum burst during trial 3 \\
\hline 2 & 195.0 & 192.6 & 110.7 & $193.8^{*}$ & $1.7^{*}$ & Pass & Coronary artery leak during trial 3 \\
\hline 3 & 192.1 & 174.3 & 173.1 & 179.8 & 10.6 & Pass & \\
\hline 4 & 185.7 & 181.8 & 158.6 & 175.4 & 14.7 & Pass & \\
\hline 5 & 157.6 & 157.7 & 156.1 & 157.1 & 0.9 & Pass & \\
\hline
\end{tabular}

*Average and standard deviation excludes trial that contained non-device related failure

The results demonstrated in Table III show that all of the samples passed the testing meaning there were no leaks at the cannula-tissue interface. The pressures at each trial represent the maximum achievable pressure during that trial. The second criteria of the test was to reach pressures of greater than $150 \mathrm{mmHg}$, which was achieved in all but two runs. The maximum pressure for Spring \#1, Pressure 3 was $131.4 \mathrm{mmHg}$, which is 
nearly $50 \mathrm{mmHg}$ less than the maximum of either of the first two pressures, 180.9 mmHg. However, during the third pressure test the septum burst producing a leak and inhibiting the pressure from rising above the maximum. The pressure was unable to continue rising because the right half of the heart was not a closed system. The maximum pressure for spring 2 pressure 3 was 110.7 , nearly $85 \mathrm{mmHg}$ lower than the maximum of either of the first two pressures, $195.0 \mathrm{mmHg}$. The cause of the lower value was due to the coronary arteries developing a leak, producing a stream of water from the heart. This prevented the pressure from rising any higher than the maximum of this run. In these two cases, the first two pressures were high and fairly consistent. It can be assumed that the pressure build up inside of the left ventricle during the first two runs lead to the malfunctions in the third run. The weakening, potentially due to the tissue of the LV expanding, of the heart tissue over the course of the three pressures can be seen with the results from springs 2,3 , and 4 , where the maximum pressure decreased with each sample. Springs 1 and 5 had a slight increase in maximum pressure from the first run to the second, and then had a decreased pressure for the third run.

TABLE IV

AVERAGE PRESSURE FROM LEAK TESTING BY WIRE DIAMETER

\begin{tabular}{|c|c|c|}
\hline $\begin{array}{c}\text { Wire } \\
\text { Diameter }\end{array}$ & $\begin{array}{c}\text { Average } \\
\text { Pressure }\end{array}$ & $\begin{array}{c}\text { Standard } \\
\text { Deviation }\end{array}$ \\
\hline 0.055 & 185.38 & 10.30 \\
\hline 0.049 & 183.48 & 7.45 \\
\hline 0.045 & 157.65 & 0.07 \\
\hline
\end{tabular}


The values in this table were derived by taking the average of the results from each trial by grouping springs together based on their wire diameter. However the third trial for each cannula was not taken into account in Table IV because of the non-device related failure during trial 3 for cannulas 1 and 2. Springs 1 and 2 were used for the .055 wire diameter, springs 3 and 4 were used for the .049 wire diameter, and spring 5 was used for the .045 wire diameter. As can be seen in Table IV, the average pressure decreased as wire diameter decreased, with a much greater decrease occurring between $.049 "$ and $.045 "$ than between $.055 "$ and $.049 "$. The wire diameter of .045 had an n-value of 1 , while the other two wire diameters had an n-value of 2, which may be the reason for the larger decrease from .049" to .045".

Limitations that may hinder the results of this test method is the use of the same heart and incision for all three tests. With the same heart being exposed to high pressures multiple times the tissue may lose integrity and alter the final results. This can be seen with the two trials where the heart failed due to leaks at the septum and coronary arteries. Variability in tissue from using a new heart per trial is also limited when using one heart for all three trials. These limitations could be taken into account by using a new heart for each trial. However, a limitation to using a new heart with each trial during this testing was the integrity of the hearts that were obtained. Most of the hearts obtained were not suitable for this procedure due to cuts made at the butcher shop. If enough suitable hearts were obtained this test should be run on multiple hearts in triplicate, rather than a single heart in triplicate. 


\section{B. Results and Discussion of Tensile Test}

The tensile pull test was performed as a pass-fail test, however, the criteria was based on a control in this study. The purpose of this device is to create a sutureless-anchoring mechanism therefore eliminating sewing rings from the implantation of the cannula. To prove that the device is capable of anchoring the cannula in the tissue at similar forces to sewing ring, four sewing rings were tested. The results of the sewing ring tests can be seen in Table VI and in FIGURE 17. The maximum force recorded during the three tensile tests for each cannula can be found in Table $\mathrm{V}$ below. The graphs showing the force over displacement for all three runs of each cannula prototype can be found in FIGURE 14 below. 

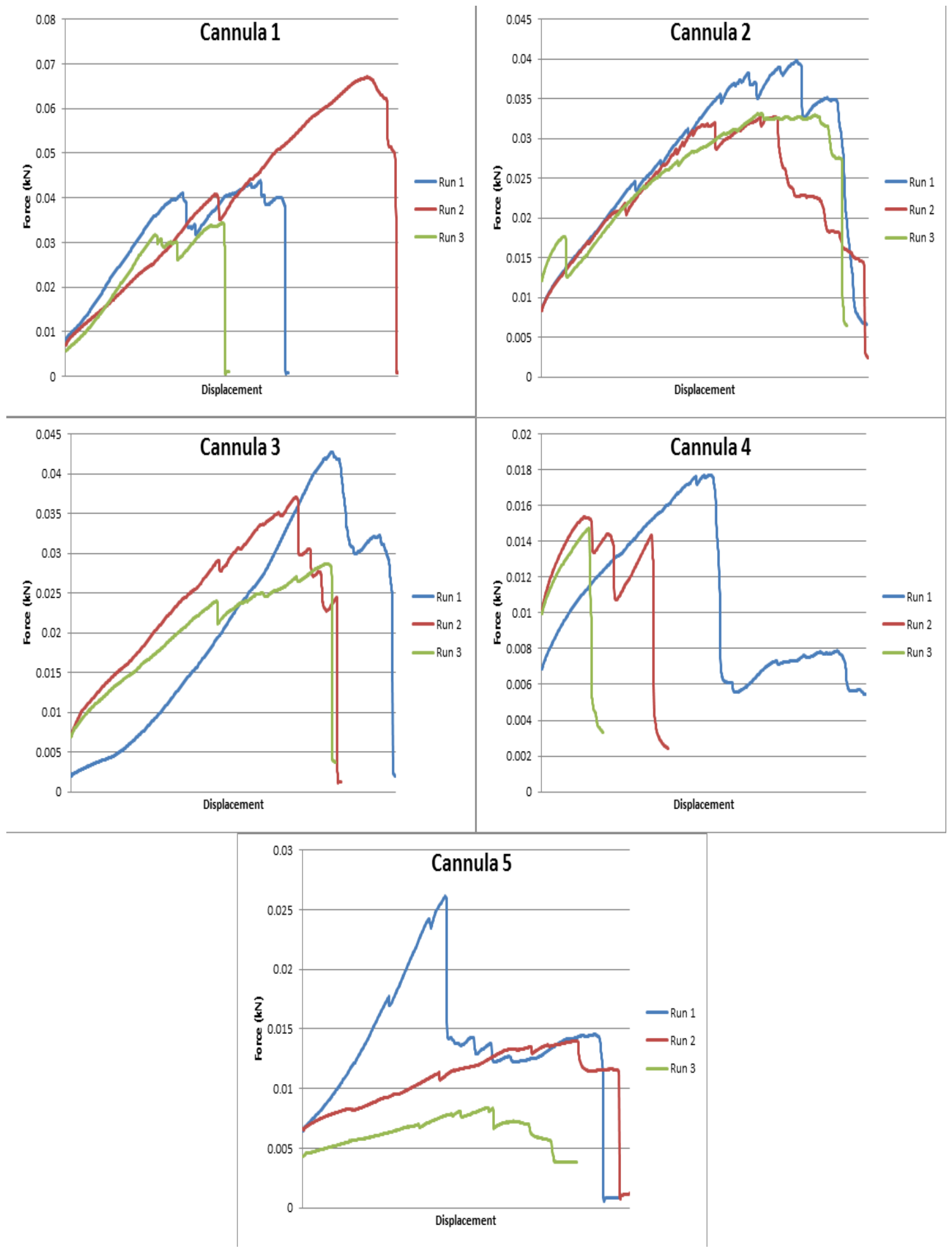

FIGURE 14- Graphs of the results from tensile pull testing for cannula prototypes 


\section{TABLE V}

\section{RESULTS FROM TENSILE TESTING}

\begin{tabular}{|c|c|c|c|c|c|}
\hline \multirow{2}{*}{ Cannula } & \multicolumn{3}{|c|}{ Maximum Force (N) } & \multirow{2}{*}{$\begin{array}{c}\text { Average } \\
\text { Force } \\
\text { (N) }\end{array}$} & \multirow{2}{*}{$\begin{array}{l}\text { Standard } \\
\text { Deviation }\end{array}$} \\
\hline & Trial 1 & Trial 2 & Trial 3 & & \\
\hline 1 & 43.84 & 67.05 & 34.4 & 48.43 & 16.8 \\
\hline 2 & 39.83 & 32.69 & 33.18 & 35.23 & 3.99 \\
\hline 3 & 42.78 & 37.05 & 28.69 & 36.17 & 7.09 \\
\hline 4 & 17.70 & 15.38 & 14.73 & 15.94 & 1.56 \\
\hline 5 & 26.12 & 14.00 & 8.38 & 16.17 & 9.07 \\
\hline
\end{tabular}

Looking at Table V, some interesting observations should be noted. The first observation is the maximum overall force for all tests and cannula is $67.05 \mathrm{~N}$, which is more than $20 \mathrm{~N}$ larger than the next highest value, $43.84 \mathrm{~N}$. Cannula 1 returned the highest average force of $48.43 \mathrm{~N}$, and cannula 4 delivered the lowest average force of 15.94 N. In four of the five cannula, the lowest of the maximum forces occurred during the final run. This may be due to small amounts of deformation or fatigue to the spring, although no physical deformations were noticed. The variance in maximum forces in each run may also be attributed to a new heart being used, and the differences in tissue thickness. The hearts used had been refrigerated for eighteen hours prior to testing, which would decrease the elasticity of the tissue, and may have affected the results. However, heart storage and preparation was consistent for cannula prototypes and sewing rings, therefore potential changes in heart elasticity should not bias comparative analysis. Future studies with more specified spring dimensions will benefit by improved study design with more runs per prototype with fresh hearts per run. 
Based on the results of tensile testing, the maximum force seems to be affected by a combination of wire diameter and the size of the large end outer diameter. This observation is based on viewing the the results from cannula 1, 2, and 3, in table VI below. As can be seen, the average maximum force for cannula 1 is larger than that for cannula 2. The only difference in the springs used for these two cannula is the large end of the springs outer diameter with the larger of the two being cannula 1. Also, cannula 3 has a larger maximum average force than cannula 2 . The differences in the springs used are length, wire diameter, and large end outer diameter. To test this hypothesis the data was input into Minitab 16 and run using best subsets and a general regression. The results from the best subsets test are in FIGURES $15 \& 16$ below. Based on the best subsets results the best model for the current data is the model that only includes wire diameter and large outer diameter as the response variables. The $\mathrm{R}-\mathrm{Sq}$ value of 94.9 in combination with a low Mallows Cp (2.1) and S-value (4.5054) show this is a good model to use. The data was then run through a general regression yielding $p$-values of 0.072 for larger outer diameter and 0.066 for wire diameter. These p-values are larger than 0.05 , meaning that the variables are insignificant in this model, proving the hypothesis wrong. With an expanded data set and the p-values in this model being near the goal of 0.05 , it can be expected that in future testing these variables would become significant.

Another interesting observation from the data is that the springs with longer lengths $(>0.75 ")$ achieved a larger average failure force than those with shorter lengths $(=0.75 ")$. This is beneficial in this study because, as stated earlier, patients with left ventricular hypertrophy, as experienced in heart failure and AS, have larger wall thickness at the 
apex. Therefore a longer spring can be used which would allow for deeper embedding into this tissue providing extra securement while in a higher pressure environment.

\section{Best Subsets Regression: Average Forc versus Length (in.), Large Quter, ...}

Response is Average Force (N)

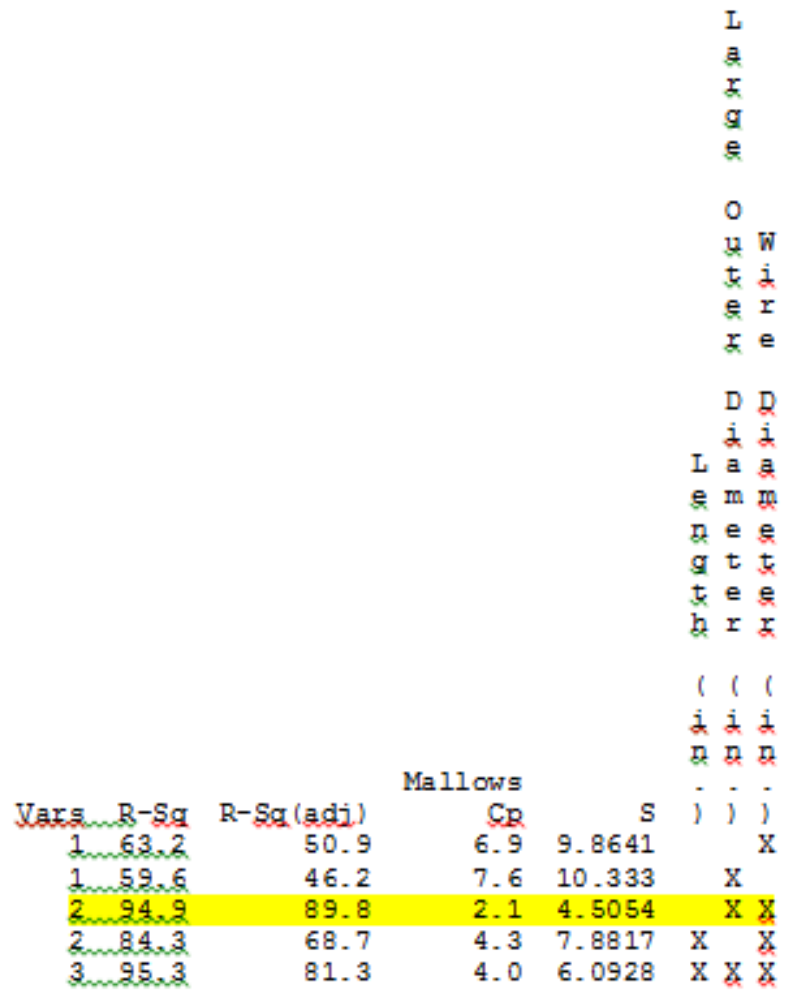

FIGURE 15- Best subsets analysis of Average Force (N) vs. Large outer diameter, Wire diameter, and length. 


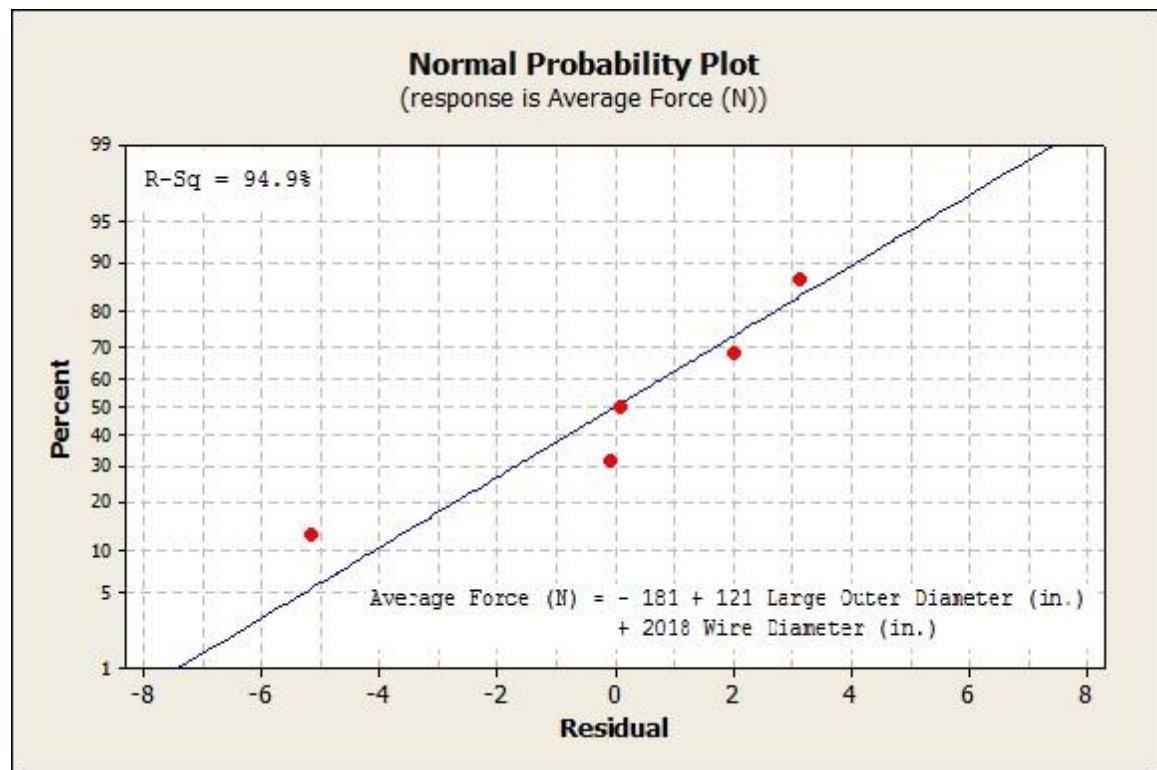

FIGURE 16- Regression analysis results of Average force vs. large outer diameter and wire diameter

To be able to prove that the design proposition of this study is a suitable replacement for current technology, sewing rings, a control had to be tested. The sewing ring tests were performed under the same conditions as the cannula prototype. The results for the four sewing rings that were tested can be found in Table VII.

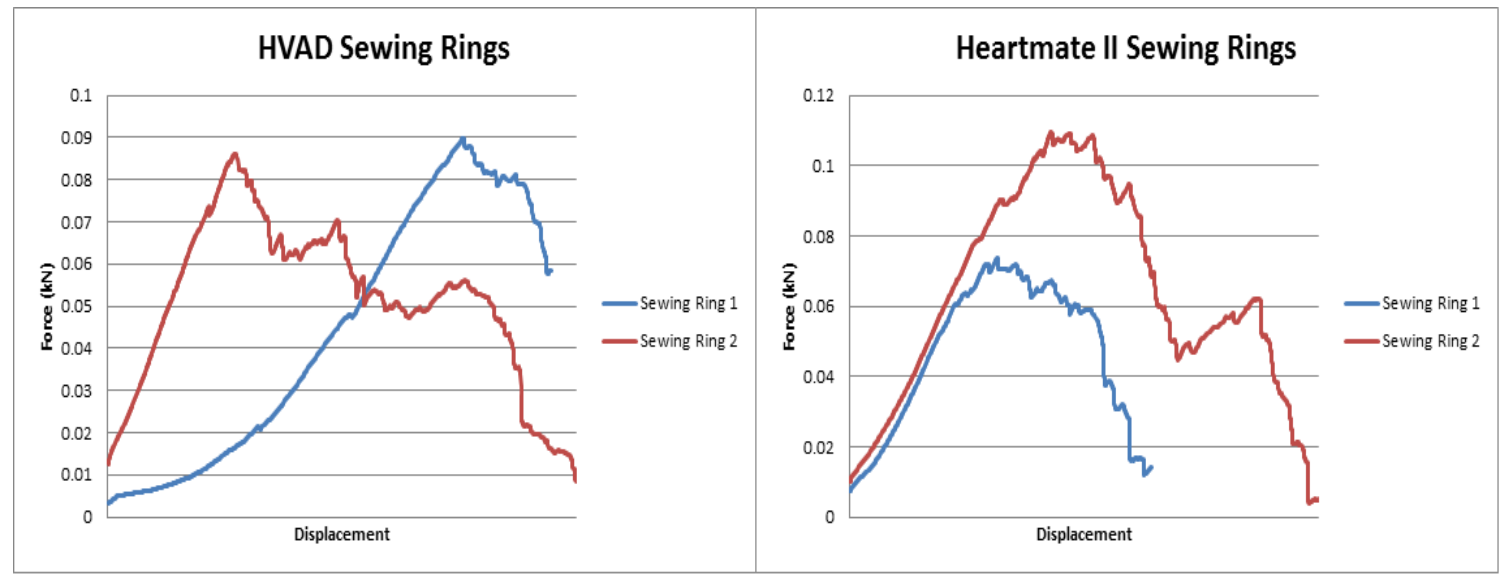

FIGURE 17: Graphs of Tensile pull test data for sewing rings 
TABLE VI

MAXIMUM AND AVERAGE FORCES FOR SEWING RING TENSILE TESTS

\begin{tabular}{|c|c|c|c|c|}
\hline & \multicolumn{2}{|c|}{ Maximum Force (N) } & \multirow{2}{*}{$\begin{array}{l}\text { Average } \\
\text { Maximum } \\
\text { Force (N) }\end{array}$} & \multirow{2}{*}{$\begin{array}{l}\text { Standard } \\
\text { Deviation }\end{array}$} \\
\hline & $\begin{array}{c}\text { Sewing Ring } \\
1\end{array}$ & $\begin{array}{c}\text { Sewing Ring } \\
2\end{array}$ & & \\
\hline HVAD & 89.79 & 86.08 & 87.94 & 2.62 \\
\hline Heartmate II & 73.64 & 109.74 & 91.69 & 25.53 \\
\hline
\end{tabular}

The results from the HVAD sewing rings were consistent with each other, while the Heartmate II sewing rings had a higher degree of variability. The average maximum force between the two brands only varied by $3.75 \mathrm{~N}$ so one brand doesn't seem to be more suitable than the other. However, the maximum and minimum forces from all the tests were achieved during the tests of Heartmate II sewing rings with a minimum force of $73.636 \mathrm{~N}$ and maximum force of $109.735 \mathrm{~N}$.

When comparing the results from the cannula prototypes and the control, Table VIII, it can be seen that the sewing rings were able to achieve greater maximum forces than the cannula prototypes. One point of interest is the maximum force of Cannula 1, 67.05 N, and the Run 1 Maximum Force for the Heartmate II sewing ring, 73.64 N, a difference of $6.59 \mathrm{~N}$. This difference in sample forces shows that the Cannula 1 prototype is nearly capable of achieving the same maximum force in a run as a sewing ring.

However, the average force difference between the cannula 1 prototype and the Heartmate II sewing rings is $43.26 \mathrm{~N}$. This could be attributed to the fact that the sewing rings $(n=4)$ were each tested once on different hearts, while each cannula prototype was 
tested three times on the same heart. Deformation may have occurred during the cannula prototype tests that lead to smaller maximum forces in later tests.

The differences in forces may also be attributed to the natural variances in hearts. Each test utilized a new heart which leads to variances outside of our control. One heart may have had a thick myocardium that allowed deep implantation of the cannula prototype, while others may have had a thin myocardium that the cannula penetrated through. If the thickness of the myocardium were measured during each test this could be determined as a significant factor, and may be something to record in future testing. Increasing the sample size in future tests will allow for a larger data set. Having duplicates of the same prototype to test will also determine if deformation is a factor in the tests. Each duplicate cannula should be tested multiple times and the results compared to determine if there is any consistency in results over the course of multiple trials, proving that deformation occurred.

Another point of variance amongst the prototypes is the circular incision made to the apex. The incision was made using a scalpel, so there was variance from one incision to the next. If the incision was too small tissue may have been damaged upon insertion of the prototype. On the contrary, if the incision was too large, the tissue may not have compressed to the prototype as well. Instead of using a scalpel, in future testing a dilator kit should be obtained that would allow for implantation using the Seldinger technique. The data obtained would be best suited to the procedure of implantation in the body. When the sewing rings were implanted in the tissue, the tissue in the center was not cored. This should not make a difference in the results of the tensile testing, however, 
future testing should core out the tissue. The extra tissue may have increased the integrity of the sewing ring leading to larger failure forces.

TABLE VII

\section{RESULTS FROM ALL TENSILE TESTS}

\begin{tabular}{|c|c|c|c|c|c|c|}
\hline Device & $\begin{array}{c}\text { Run 1 } \\
\text { Maximum } \\
\text { Force (N) }\end{array}$ & $\begin{array}{c}\text { Run 2 } \\
\text { Maximum } \\
\text { Force (N) }\end{array}$ & $\begin{array}{c}\text { Run 3 } \\
\text { Maximum } \\
\text { Force (N) }\end{array}$ & $\begin{array}{c}\text { Average } \\
\text { Force } \\
(\mathrm{N})\end{array}$ & $\begin{array}{c}\text { Standard } \\
\text { Deviation }\end{array}$ & $\begin{array}{c}\text { Maximum } \\
\text { Force (N) }\end{array}$ \\
\hline Cannula 1 & 43.84 & 67.05 & 34.4 & 48.43 & 16.80 & 67.05 \\
\hline Cannula 2 & 39.83 & 32.69 & 33.18 & 35.23 & 3.99 & 39.83 \\
\hline Cannula 3 & 42.78 & 37.05 & 28.69 & 36.17 & 7.09 & 32.43 \\
\hline Cannula4 & 17.7 & 15.38 & 14.73 & 15.94 & 1.56 & 17.7 \\
\hline Cannula5 & 26.12 & 14 & 8.38 & 16.17 & 9.07 & 26.12 \\
\hline HVAD Sewing Ring & 89.79 & 86.08 & & 87.94 & 2.62 & 89.79 \\
\hline Heartmate II Sewing Ring & 73.64 & 109.74 & & 91.69 & 25.53 & 109.74 \\
\hline
\end{tabular}

Interesting observations to make about the graphs in FIGURE 13 is that in most tests there is a maximum peak followed by a drop in force, followed by an increase in force. Sometimes this trend occurs more than once. This was the result of one portion of the spring being pulled from the tissue. As the spring was pulled from the tissue, it came out in layers because of the turns. After one portion would rip out of the tissue the rest of the spring embedded in the tissue would remain secured in the tissue until the next portion of the spring would tear from the tissue. If deformation were to occur, it is hypothesized that, this is the point in which it would. For instance, if a large force was achieved after the first portion of the spring was removed from the tissue, while the rest of the spring remained secure, deformation may occur at this point. With each spring being used in multiple tests the chances of deformation occurring increased significantly versus if a spring was used only once. 
The only time the cannula would experience tensile forces, similar to this test, in the body would be if the surgeon were to apply force after implanting the cannula to ensure proper placement. The only other forces the cannula should come in contact with are the compressive and tensile forces on the cannula from the heart beating and if there is any weight associated with the graft as it fills with blood. These forces are not expected to overcome the forces the cannula would experience in this tensile testing.

This study did not take into account a long term analysis of the cannula prototypes and their interactions with the tissue. This device is intended for implantation in the heart so fatigue could become an issue as the number of heartbeats experienced increases over time. This should be simulated using a method that mechanically reproduces the cyclic nature of the beating heart.

\section{Results and Discussion of the Quantitative Feasibility of Implantation Survey}

The completed survey forms for the quantitative survey of device can be found in APPENDIX I. Table VIII shows the results per each question. One of the survey participants thought the spring was very easy to initially penetrate the tissue, was very easy to fully implant in the tissue, was less difficult to administer than a suture ring, but would still like to include suturing with the device. The other survey participant varied from the first participant by thinking that the spring wasn't very difficult or easy to initially penetrate the tissue, but was in the middle, and that they thought the device was only easy, not very easy, to fully implant in the tissue. Some comments that were received are as follows, "Little hard to start, but moves easily through the myocardium. However, it may be a little too easy to some degree." The results 
from the survey validated the design goals that the device would be easier and quicker to implant than a sewing ring. However, at the current stage of development a mentality persists that a sewing ring is a better solution. This survey should be administered to more CT surgeons in the future to continue to expand the results from Table VIII. The need for an additional sewing ring to be included with the cannula may be due to the crudeness of this initial prototype. As the study progresses, and specific dimensions are determined for the spring, a final prototype should be fabricated using pyrolytic carbon (PYC) as the cannula material with the screw embedded in the PC. The survey should then be administered to the CT surgeons again to determine if their decision on needing a sewing ring has changed. Even still, only in vivo pre-clinical testing will determine if redundant attachment systems are necessary.

TABLE VIII.

\section{RESULTS OF QUANTITATIVE SURVEY OF DEVICE}

\begin{tabular}{|c|c|c|c|c|c|c|}
\hline Question & \begin{tabular}{|c|} 
Difficult \\
1 \\
\end{tabular} & 2 & & & 4 & $\begin{array}{l}\text { Easy } \\
5\end{array}$ \\
\hline How difficult was it to make initial penetration? & & & & & & 1 \\
\hline \multirow[t]{2}{*}{ How difficult was it to fully implant the screw into the tissue? } & & & & & 1 & 1 \\
\hline & \multicolumn{2}{|c|}{ Difficult } & & & \multicolumn{2}{|c|}{ Easy } \\
\hline \multirow[t]{2}{*}{$\begin{array}{l}\text { Would this be more difficult, less difficult, or the same to administer } \\
\text { than a sewing ring? }\end{array}$} & & & & & \multicolumn{2}{|c|}{2} \\
\hline & \multicolumn{3}{|c|}{ Trust by Itself } & \multicolumn{3}{|c|}{ Include Sutures } \\
\hline $\begin{array}{l}\text { Would you trust this method by itself or would you still prefer to add } \\
\text { suturing? }\end{array}$ & & & & \multicolumn{3}{|c|}{2} \\
\hline
\end{tabular}




\section{CONCLUSIONS}

Based on the results from the leak testing it can be concluded that all cannula prototypes are capable of maintaining a leak proof seal at the cannula-tissue interface during high pressures similar to those experienced during severe aortic stenosis. The results of the tensile pull testing show that none of the cannula prototypes are capable of achieving failure forces of sewing rings. The cannula that was able to achieve the highest forces was Cannula prototype 1 which, in conjunction with leak test results, can be called the best overall performing prototype. This prototype had a large wire diameter and a large open end wire diameter. The results of the quantitative survey of the device showed that the device was less difficult to administer than a sewing ring, but the participants would still like to include sutures during a procedure as a precaution. It can be concluded that there is promise for the device to be successful in the future, but the tests need to be expanded to include springs with larger outer diameters and wire diameters, and in vivo studies should be performed to determine efficacy. 


\section{RECOMMENDATIONS}

While none of the prototypes were capable of achieving failure forces that were better than the forces achieved by the sewing rings, the second run of the first cannula did produce a result similar to that of the Heartmate II sewing ring. One hypothesis for why the failure force results for all the cannula prototypes decreased over time is that there was deformation that occurred. To test this hypothesis three Cannula 1 prototypes should be made. Each of these cannula should be tested at least three times and then the results compared. This will allow the tester to see if the cannula is capable of achieving higher forces, but also to see if the failure force decreases gradually during each test, proving that there is deformation occurring. Additional tests should be run on the sewing rings to ensure accurate data, especially on the Heartmate II sewing ring which had a range of 36.1 $\mathrm{N}$ in the two tests. Additional tests would help pinpoint a more accurate average failure force.

Based on the results of the tensile tests a rough hypothesis was formulated suggesting that larger wire diameters in conjunction with larger open end outer diameters lead to higher failure forces, however this was not supported by statistical analysis at this low sample-size. However, it can be expanded for future tests by testing springs with larger wire diameter and open end outer diameter combinations to determine whether any of the factors are significant with a larger data set. The spring selection from McMasterCarr is limited so another conical spring provider should be found, however, ordering custom springs also serves as a viable option. The length will remain constant in future testing (1") because this provides adequate securement based upon our results. It would not be detrimental to vary the spring length in future studies, once the appropriate wire 
diameter and large outer diameter combination has been found, to further determine the effects of length on test results. If this path is pursued the anatomical limitations previously stated would still need to be taken into account so the spring does not penetrate the left ventricle. While this study may not have been able to prove that any of the springs used are capable of removing the need for sewing rings during apical cannula implantation, it did provide valuable results for future studies. The processes used in this study have room for improvement, with fabricating multiple prototypes for springs with the same dimensions. There is promise for this method to become the surgical implantation method of the future, but more testing needs to be conducted to prove that one spring is consistently able to provide a leak proof tissue-cannula interface, higher tensile forces than sewing rings, and positive reviews from CT surgeons.

The springs recommended for future testing can be found in table IX. These springs have a constant length of 1", but has varying wire diameter (.055-.060") and large end outer diameter (.975-1.25”). The results from these springs combined with the results from the springs in this paper should be combined and analyzed statistically to determine significance of factors. Duplicates of each spring should be obtained to make multiple prototypes of each number. This will allow for a larger data set to be obtained during tensile testing, if each prototype is tested multiple times. 
TABLE IX

\section{RECOMMENDED SPRINGS FOR FUTURE TESTING}

\begin{tabular}{|c|c|c|c|}
\hline \multirow{2}{*}{$\begin{array}{c}\text { Spring } \\
\text { Number }\end{array}$} & \multicolumn{3}{|c|}{ Spring Dimensions (in.) } \\
\cline { 2 - 4 } & Length & $\begin{array}{c}\text { Wire } \\
\text { Diameter }\end{array}$ & $\begin{array}{c}\text { Large end } \\
\text { outer } \\
\text { diameter }\end{array}$ \\
\hline 1 & 1.00 & 0.055 & 1.15 \\
\hline 2 & 1.00 & 0.055 & 1.25 \\
\hline 3 & 1.00 & 0.060 & 0.975 \\
\hline 4 & 1.00 & 0.060 & 1.15 \\
\hline 5 & 1.00 & 0.060 & 1.25 \\
\hline
\end{tabular}

Cannulation of the LV apex for AVB and VAD implantation can be time consuming and lead to bleeding complications or inflow occlusion. The goal of this project was to develop a sutureless-anchoring device for an apical left ventricular (ALV) cannula system. Through leak testing, tensile pull testing, and a quantitative assessment of the device by CT surgeons it was deemed that none of the springs tested in this study were capable of performing better in these tests than sewing rings. However, there was one spring that was capable of achieving a tensile force similar to that of a sewing ring. The results of that test in conjunction with the results from leak testing and the feedback given from CT surgeons show that there is promise this design could potentially replace the need for apical coring and cannulation during AVB and VAD implantations. 


\section{LIST OF REFERENCES}

1. Chin, D. (2009). "Echocardiography for transcatheter aortic valve implantation." European Journal of Echocardiography 10(1): i21-i29.

2. Bermejo J. The effects of hypertension on aortic valve stenosis. Heart. 2005;91:280-282.

3. Slaughter, M. S., et al. (2010). "Clinical management of continuous-flow left ventricular assist devices in advanced heart failure." The Journal of heart and lung transplantation : the official publication of the International Society for Heart Transplantation 29(4): S1-S39.

4. Abiomed. 2010. Impella LD with the Impella Console Circulatory Support System Instructions for use \& Clinical Reference Manual.

5. Losi, M. A., et al. (2010). "Echocardiography in patients with hypertrophic cardiomyopathy: usefulness of old and new techniques in the diagnosis and pathophysiological assessment." Cardiovasc Ultrasound 8: 7.

6. Reddy, M., et al. (2008). "Apical hypertrophic cardiomyopathy: potential utility of Strain imaging." Eur J Echocardiogr 9(4): 560-562.

7. Chambers, J. (2006). "The left ventricle in aortic stenosis: evidence for the use of ACE inhibitors." Heart 92(3): 420-423. 


\section{APPENDIX I}

QUATITATIVE FEASIBILITY OF IMPLANTATION SURVEY AND

RESULTS 
On a scale of 1-5 with 1 being very difficult and 5 being very easy, how difficult was it to make initial penetration into the tissue?

1

2

3

4

5

Additional Comments:

On a scale of 1-5 with 1 being very difficult and 5 being very easy, how difficult was it to fully implant the screw into the tissue?

1

2

3

4

5

Additional Comments:

Would this be more difficult, less difficult, or the same to administer than a sewing ring?

$\begin{array}{lll}\text { More Difficult } & \text { Less Difficult } & \text { The Same }\end{array}$

Additional Comments:

Would you trust this method by itself or would you still prefer to add suturing?

Trust by itself Prefer to include sutures

Any other comments or advice you may have? 
On a scale of 1-5 with 1 being very difficult and 5 being very easy, how difficult was it to make initial penetration into the tissue?

1

2

3

4

Additional Comments:

On a scale of $1-5$ with 1 being very difficult and 5 being very easy, how difficult was it to fully implant the screw into the tissue?

1

2

3

4

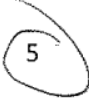

Additional Comments:

Would this be more difficult, less difficult, or the same to administer than a sewing ring?

More Difficult

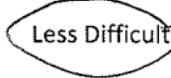

The Same

Additional Comments:

Would you trust this method by itself or would you still prefer to add suturing?

Trust by itself

Prefer to include sutures

Any other comments or advice you may have? 
On a scale of 1-5 with 1 being very difficult and 5 being very easy, how difficult was it to make initial penetration into the tissue?

12

2

4

5

Additional Comments:

On a scale of 1- 5 with 1 being very difficult and 5 being very easy, how difficult was it to fully implant the screw into the tissue?

2

3

(4)

5

Additional Comments

Would this be more difficult, less difficult, or the same to administer than a sewing ring?

More Difficult

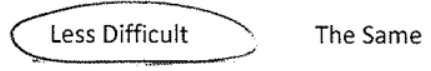

Additional Comments:

Would you trust this method by itself or would you still prefer to add suturing?

Trust by itself

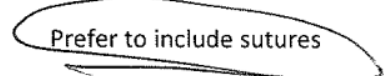

Any other comments or advice you may have?

Little hard to start, but moves easily through
the myocardium. However, it may be al litte foo
easy to some degree. 